\title{
Misunderstanding home: exploring depictions of home in old-age policy decision-making
}

\author{
By JutTa PuLKKI ${ }^{1} \mathcal{E}$ LiInA-Kaisa TYNKKYNeN ${ }^{2}$
}

\begin{abstract}
Living at home is a core value in old-age policies worldwide. This study examines how members of parliament (MP) depicted the home in two parliamentary discussions related to a law on older people's care and living arrangements in Finland. The data contained 110 speeches from 42 MPs in the first discussion and 17 in the second and were examined using thematic analysis. The extracts with the word "home" were coded and grouped as potential themes. These themes were reviewed further and reflected using relevant literature. As a result, the overarching theme, "home as a restricted space," was formulated with three subthemes: home as a space in which old people "manage to live," "are treated" and "live without contacts." The findings suggest that policymakers misrecognised the valued attributes related to older persons' homes, and in doing so, they hampered the potential for success in home-centred old-age policies. Keywords: ageing in place, Finland, policymakers, thematic analysis.


International Journal of Ageing and Later Life

\section{Introduction}

Ageing in place, especially living at home for as long as possible, is a core value of old-age policies worldwide (Genet et al. 2011; Means 2007). The home has replaced institutional settings such as nursing homes and residential care as the most desirable place for older people (Means 2007). Living at home is promoted as a goal to which older people themselves aspire. The home has also been seen as a means to alleviate the financial pressures of the ageing population in the public sector (Means 2007; Tarricone \& Tsouros 2008).

In spite of the strong emphasis on home-centred old-age policies, the concept of home has rarely been explicitly specified in politics. The home is, at the same time, a common and familiar word, and an elusive concept, with many meanings and possible definitions. Oswald and Wahl (2005: 21) have argued that the diversity of the meanings of home "hinders an understanding of what 'Ageing in place' is all about." This is seen in how the concept of "ageing in place" is used. Ageing in place has been associated with staying put in one's current home, within one's own four walls; others have interpreted ageing in place, as well as the concept of home, more broadly, as referring to living in a familiar community and moving within it if necessary (Means 2007). Vague understandings of the concept of home in home-centred old-age policies, such as the goal of ageing in place, may result in unwanted practices, for example, keeping older persons in their current homes in spite of their changing needs.

To our knowledge, there are no studies that address policymakers' perceptions of home, even though their underlying understandings of home direct the content and scope of the home-centred policies and thus affect the everyday lives of older people. Furthermore, statements made by policymakers are widely reported in the media and hence become involved in the broader process of constructing a shared societal understanding of older people's homes and care.

This study fills in these gaps in knowledge by exploring how policymakers depict the home when they debate living and caring arrangements for older people. The research question is: how do policymakers who are at the centre of old-age policies, and who are responsible for designing policies for publicly offered care and living arrangements, understand and depict the homes of older people? By investigating the concept 
of home in the political debate, we offer a deeper understanding on the basis of the current policy of ageing in place and contribute to evolving that policy further.

We conducted this study by reviewing speeches by MPs during two parliamentary sessions in Finland. The discussions were part of the legislative process surrounding the Act on Supporting the Functional Capacity of the Older Population and on Social and Health Care Services for Older Persons (enacted 1 July 2013, amended autumn 2014). This was the first legislative initiative in Finland specifically directed towards the older population and their services.

\section{Multiple Meanings of Home}

Home is a widely studied concept in many disciplines. It has been analysed through various ideas such as being at home, feeling at home, or creating or making a home (Mallett 2004), and from the perspective of the ideal home (Chapman \& Hockey 1999). However, Easthope (2004) has argued that it is impossible to provide a single, solid definition of the term "home." This is because a home has different meanings for different people, and those meanings change over time. Thus, instead of trying to find a solid definition, a common way to approach the concept is to study its meanings (Rowles \& Chaudhury 2005: 3). Oswald and Wahl (2005: 22) remarked that the meaning of home comes into existence in the relationship between objective socio-physical settings and subjective goals, values and emotions. The meaning of home is composed of shifting physical, social, cultural and symbolic contexts (Moore 2000), as well as personal features (Oswald \& Wahl 2005).

Watkins and Hosier (2005) have suggested that the home has both experienced and imagined attributes that alter during the life course. Experienced home comprises everyday experiences of being at home, feeling at home and creating a home; imagined home is a more rigid idea emerging from the person's preferences and values, which reflect both positive and negative experiences of the home. According to Watkins and Hosier (2005: 205), "being fully at home requires conformance of the experienced and imagined home." However, this becomes especially compromised in late life when the experienced home may not conform to the imagined home, for example, due to the person's physical or mental decline. 
International Journal of Ageing and Later Life

Another way to approach the home is to distinguish it from related concepts, such as "house." In these distinctions, a home is referred to as an intimate place of belonging, whereas a house is more of an objective, concrete setting, which can be observed and evaluated (Oswald \& Wahl 2005: 22). Relatedly, the home has also often been defined as a place or space. Space refers to a physical home with walls, while the home as a place goes beyond the physical space to address interactions with the surroundings, and thus is often constructed by the meanings that people attribute to it (Easthope 2004). Currently, it is commonly argued that a home is not just the four walls of a limited space. Rather, its boundaries extend beyond the physical space to the neighbourhoods and even to a whole area of living, such as one's home town (Easthope 2004; Ewart \& Luck 2013; Mallett 2004).

If a home is understood as a comprehensive place and not merely a physical location, it is possible to entertain the idea that people can carry their home with them wherever they go (Ewart \& Luck 2013). Vilkko (2000) has presented the concept of "home enough," in which it is acknowledged that the home is something people can carry with them when they move. You may not be in the same house, but the little things you take with you, and the memories related to them, can still make the new space and place feel "home enough." This notion can also be found in ageing in place policies. Wiles et al. (2012), for example, have suggested that, "when we think about ageing in place and ways to support people to 'stay put,' we need to recognise that place is a process and operates at different scales and sites." That is, the meaning of home fluctuates during the life course, alongside social, physical and cognitive changes (Chapman \& Hockey 1999). Hence, the understanding of the home as the basis of old-age policy ought to be flexible.

\section{Home in Later Life}

There is a diverse body of literature on older adults' perceptions of home and living at home (Gillsjö et al. 2011; Gott et al. 2004; Haak et al. 2007; Mortenson et al. 2016; Oswald \& Wahl 2005; Seymour et al. 2007; Stones \& Gullifer 2016). Sixsmith and Sixsmith (2008) found that older homedwellers defined their homes in a comprehensive manner. The home was 
a place of privacy and security that provides a sense of control over one's life, but it was also vital to one's ability to interact with family and friends (Sixsmith \& Sixsmith 2008). Also, Nicholson et al.'s (2013) study on frail older persons highlighted the importance of others in supporting their capacities and quality of life while living at home.

It has been shown that older persons can maintain their independence, even though their physical abilities are on the decline, if they can learn how to adapt their lives in a familiar place (Kontos 1998; Sixsmith \& Sixsmith 2008). Indeed, the sense of independence is an important reason why older people want to stay at their permanent home (Kontos 1998). Living at home is also found to be one of the things that help older people to continue to experience a good quality of life (Borglin et al. 2005). Living at home has been found to support older people's self-image, personal interests and identity (Haak et al. 2007; Kontos 1998), while leaving home can mean giving up all these valuable aspects of life (Gillsjö et al. 2011).

Even though living at home is a frequent aspiration, not all older persons can or desire to stay in their current home, and living at home can be challenging or have several negative aspects. In a study by Sixsmith and Sixsmith (2008), home-dwelling older persons reported physical barriers (both inside, such as stairs, and outside, such as transport access), fearfulness (e.g. of violence or falls) and loneliness. Indeed, loneliness is one of the clearest drawbacks of living at home, especially for older people living alone (Eloranta et al. 2015; Savikko et al. 2005; Theeke 2009).

Some people may continue to live at home even though they do not feel it is an ideal place. Hillcoat-Nallétamby and Ogg (2014) found that older persons disliked their current homes and wanted to move, but they were so attached to the people in their neighbourhood that they decided not to. Older people may also prefer to stay at home because they do not want to move into an institution (Pirhonen et al. 2015). That is, they choose not to move into an institution, rather than actively choosing to live at home as the best alternative (Pirhonen \& Pulkki 2016). Besides, even if older persons prefer to receive end-of-life care at home, they do not necessarily want to die at home, because they do not want to be a burden to their relatives or because they are afraid of dying alone (Gomes et al. 2013; Gott et al. 2004; Seymour et al. 2007). 
International Journal of Ageing and Later Life

\section{Context of the Study}

The political debate over the best place for older people's care and living has been ongoing in Finland for many decades (Kaskiharju 2010), and this debate has followed international trends in old-age policies (Means 2007). While institutional care arrangements were previously considered mainstream solutions, the emphasis has now shifted towards home-based care practices. During the past decades, older people living and being cared for at home has been the primary aim of many Finnish policy documents (e.g. Ministry of Social Affairs and Health 2001, 2008).

Currently, long-term care arrangements for older people in Finland include home care, sheltered housing or service houses and institutional care provided in nursing homes (Johansson 2010). Service housing is regarded as home-based care, because the older persons rent their apartments from a service house facility. Also, people living in service houses pay for their services, such as home care, akin to those living in their own private homes. There are also new initiatives for shared or group housing and senior houses that provide older people with a more communal type of living (Jolanki \& Kröger 2015); however, these are not yet widely available in Finland.

Currently, old-age care services are the responsibility of 300+ municipalities in Finland. Municipalities have had the autonomy to organise services for older people, whereas the national-level steering and governance of old-age care policy has been rather weak (Keskimäki et al. 2019). This situation has led to substantial variation in the organisation of services across the country, including in long-term care utilisation (Kokko \& Valtonen 2008). In line with ongoing international trends and national old-age policy, institutional care has been cut back in many municipalities and replaced by sheltered housing. Of people aged 75 and older, $91.9 \%$ lived at home, and 11.3\% received home care in the year 2017 (Official Statistics of Finland 2018: 58, 228).

The Act on Supporting the Functional Capacity of the Older Population and on Social and Health Care Services for Older Persons was launched in 2013 to strengthen national-level steering and decrease regional disparities in the availability of old-age care services. The explicit aim of the ACT was to assure individual social and health care services and care for aged people, namely, those individuals, throughout the country, who 
have weakened physical, psychological, cognitive or social functioning due to old age. The objective of increasing care and living at home was also embodied in the Act (Finlex 2012). This objective was reinforced by an amendment to the Act in 2015, which stated that institutional care should be provided to older people only if there was a medical need for it. Besides this very general basis, there are no strict eligibility criteria for institutional care, nor for home care services, in Finland. Instead, all municipalities can decide for themselves as to whom they should offer their services.

The rationale behind the act largely reflected international policy ideas regarding ageing in place (Genet et al. 2011; Means 2007). Firstly, the number of older people is rapidly growing in Finland as well as in many other countries. It is projected that in 2030, almost $9 \%$ of the Finnish population (500,000 inhabitants) will be over 80 years of age (Statfin 2016). The common trend is for the use of social and health services, including long-term care, to be concentrated on the people aged 85 or older (Official statistics of Finland 2018: 65); thus, the use of services is predicted to increase due to the longevity and growing number of older people. Secondly, in Finland - as in other countries with an inclusive public welfare system, including public responsibility for long-term care - there is a strong incentive for policymakers to seek solutions to tackle the needs of the older population (Batljan \& Lagergren 2005). The demand for services will occur in the context of decreased public finances, which further emphasises the need for new ways of organising old-age care that are simultaneously economically and socially sustainable.

\section{Materials and Methods}

\section{Data}

The data for this paper consist of two parliamentary discussions by MPs in Finland. Both relate to the legislative process concerning the Act on Supporting the Functional Capacity of the Older Population and on Social and Health Care Services for Older Persons. The discussions took place during the process when the bill was passed on to the parliament for further preparation. In the Finnish parliamentary process, this preliminary debate is the stage where MPs can publicly take a stance on a bill and its content. 
International Journal of Ageing and Later Life

The first discussion was held on 14 November 2012, when MPs debated whether to launch the Act. In the second discussion, held on 18 November 2014, the MPs talked about suggested amendments to the Act. There are 200 MPs in the Finnish parliament, of which 42 MPs made overall 65 speeches in the first discussion, and 17 MPs gave 55 speeches in the second discussion. The transcripts of these discussions were altogether 78 pages long. The first discussion focussed on the general rationale of the Act, while the second focused particularly on living and caring arrangements for older people because the content of the amendments addressed eligibility for institutional care. The transcripts of the discussions are publicly available on the Finnish parliament's website.

In the first discussion, MPs from government and opposition parties alike praised the Act and most of its aims and content. The most debated issues were whether the Act could offer a solution to the rising public cost of care and whether the staffing rate in institutional care was sufficient. It seemed that in this first discussion, it was easy for policymakers to support the Act. Following Starke's (2006) argumentation about political processes, this might be because the Act offered a possible solution to an economic crisis while at the same time also providing better services and fulfilling older people's wishes. Thus, the need for the Act was acknowledged by all the policymakers, which subsequently framed the parliamentary discussions.

The second discussion was more argumentative, as the opposition disagreed that there was any need to amend the Act. In this discussion, the focus was especially on living and caring arrangements, as the government wanted to alter - or from the perspective of the opposition to restrict - the basis for long-term care. The MPs from the government parties used arguments such as "an institution is nobody's home" or that "we need to develop home-based services instead of institutional care." At the same time, the opposition MPs stated that, "the home is not always the best place." They also argued that restricting access to long-term care would impair both the Act and the situation of older people. In spite of the criticism, the government's proposal was approved, and only minor revisions were made to it during this process.

In principle, parliamentary debates are arenas where MPs may present their stance and persuade the audience on a suggested act publicly. 
Thus, while doing home-centred policy, it could be presumed that MPs would use vivid - and most influential - arguments for why living and caring at home should or should not be promoted.

\section{Thematic Analysis and Focus}

This study sought to examine how policymakers depicted "home" while they were debating older people's living and care arrangements in the context of two parliamentary discussions concerning a central piece of legislation regulating old-age care policies in Finland. Thematic analysis was used to identify and analyse repetitive patterns of "home" in the data (Braun \& Clarke 2006).

The analysis concentrated on one particular aspect of the data, namely, the arguments about and descriptions of home. The analysis was first and foremost semantic. When refining the themes, attention was also paid to latent meanings of home and things that were not stated. The analysis was first conducted inductively, but this data-based analysis changed into a more theory-driven form of interpretative analysis during the definition of the final themes (Cmpr. Braun \& Clarke 2006).

The focus was deliberately on the concept of home only, and references to other living places were not considered for three reasons. Firstly, in a previous study, we had already analysed how MPs talked about places of living in general. We found three discourses in how the MPs constructed older people's dwelling places: "activating place," "fluctuating place" and "unsuitable place." Each of these three discourses also referred to the home, and the discourses varied in the importance they gave to living in one's own home and to the need to move from one place to another. As this previous study had a broad focus on living places, it failed to examine the "home" to which the policymakers were referring (Pulkki et al. 2017).

The second reason we focussed on the concept of home was that, in Finland and most other Western countries, the home is a central concept around which the contemporary debate on old-age care policies revolves. Finally, to our knowledge, there have been no previous studies that focus solely on how policymakers define home. Studying how the word "home" is used and what remains to be said will increase our understanding of the basis of home-based policymaking. 
International Journal of Ageing and Later Life

\section{Analysis}

The question, "What does this tell us about the homes of older people?," guided the analysis throughout the process. The analysis began by focussing on semantic statements about home (cmpr. Braun \& Clarke 2006). Data extracts that included the word "home" and its various formulations were identified: in the first debate, the home was mentioned 120 times and in the second 222 times. After all the relevant extracts were identified, their core meaning or message was compacted, that is, the extracts were coded. These coded extracts were then grouped as potential themes and named based on their content.

As a result of the phase called "searching for themes" (Braun \& Clarke 2006), the six most potential themes were identified. The first potential theme consisted of several statements where the home was said to be the "best place to live." The second theme included descriptions where the home was not considered the best place. The third potential theme included data extracts where MPs compared other places to the home and drew distinctions between what is and is not a home. A fourth and highly evident theme consisted of extracts where living at home was described in terms of "managing" or "coping." The fifth theme comprised extracts where the home was described as a place where care was offered. The final potential theme consisted of statements implying that older people were lonely in their own homes.

These potential themes were further reviewed (cmpr. Braun \& Clarke 2006) based on what they revealed about the home as a concept. In this phase, three potential themes - "home as the best place," "home as not the best place" and "home as separate from other places" - were collapsed, as they were considered to represent the characteristics of a home. Also, even though the home was often mentioned to be the best place for older people, this was not explained in any way. Thus, the data did not contain solid support to build up a final theme regarding the positive aspects of a home. The three remaining themes were left unchanged, as each told a specific story. The potential theme, "home as a place to manage," concerned older people's ways of living in their homes; "home as a place for care" concerned the purpose of a home; and "home as a lonely place" concerned what life at home was like. At the end of this phase, we had four themes to refine further (Braun \& Clarke 2006): characteristics of a 
home, home as a place to manage, home as a place for care and home as a lonely place.

These semantic-based themes were further refined in relation to the latent meanings of home in the whole data set, that is, the themes were tested and, if found to be sufficient, were augmented with general notions from the whole data set. From this point onwards, the analysis became more interpretative, as theories, concepts and ideas from the literature were used to define the essence of each theme (cmpr. Braun \& Clarke 2006).

\section{Results}

As a result of the thematic analysis, one overarching theme and three subthemes of the home were formulated. The overarching theme "home as a restricted space" captures the attributes of the homes of older people. This overarching theme was classified into three subthemes that described older people's ways of living in their homes, the purpose of a home and what life at home was like. These subthemes demonstrated that living at home was associated to merely managing, that the purpose of home was to be an arena for care and that life at home was isolated. To sum up, the homes of older people were depicted as restricted spaces where older persons manage to live, are treated and live without contacts (see Figure 1).

There were no significant differences between the political parties in the views of the home captured in the themes. However, some arguments were more often presented by MPs from the government and some by the

Figure 1. The overarching theme of home and its sub-themes

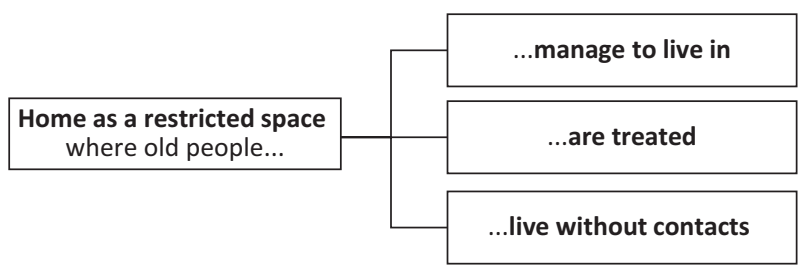


International Journal of Ageing and Later Life

opposition. At the end of each excerpt below, added in brackets is whether the MP was from a governmental (Gov.) or opposition (Opp.) party, and the year of the debate.

\section{Home as a Restricted Space}

The home was often referred to as "the best place to live" and the place where older people wanted to live, but it was not commonly agreed as to what the word "home" actually means. In most of the discussion, the definition of home was implicitly and explicitly restricted to one's own private and permanent space. Rather than describing the home as a place in its own right, MPs contrasted the home with other living places. Firstly, the home was distinguished from institutions. MPs on both sides, but especially from government parties, stated both implicitly and explicitly that "an institution is nobody's home." It was suggested that institutional care was a temporary solution, even for people with dementia who needed 24-hour care, which reflected the nature of the amendment to the law made in 2014. At the same time, however, dying at home was seen as exceptional, implying that living in institutions at the end of life was very common. The following excerpt is from the speech where an MP advocated living at home but recognised the role of institutions as a short-term care facility at the end of life:

Only a few of us manage to live at home through the end of life. It is often the case that in the last months, there is a period when institutional care is the only option. That is why it is needed, but it should not be a long-term solution. (Gov., 2014)

The home was thus separated from institutions: institutions were considered spaces to stay in for a short while or to die in, rather than places into which people could or should take or rebuild their home (Ewart \& Luck 2013; Vilkko 2000).

Even though MPs occasionally said explicitly that "sheltered houses are homes for older people" or that "all places other than institutions are homes," the home was often presented implicitly as the opposite of living in other kinds of community settings. For example, it was suggested that, "older persons may move into sheltered housing when they cannot manage to live in their own homes." 
Other places, such as sheltered housing, service houses, group homes, were mostly presented as solutions to feelings of loneliness and insecurity in one's own home; however, these alternative places were not referred to as a home but as a "home-like arrangement." That is, the line between home and other kinds of living arrangements was not clear to MPs when they were arguing about increasing living at home. This conceptual indeterminacy reflects the complexity of the old-age care system in Finland, which offers different forms of living arrangement and care for older people but has no shared understanding of the nature of these different forms (see also Pulkki et al. 2017).

Even though the home was said to be "the best place to live," there were no explicit descriptions of what made the home superior to other living arrangements. No positive attributes were presented related to the home other than the claim that "older people themselves want to live at home." Indeed, the home was not actually portrayed as the best place to live in all situations. In particular, it was relatively common for MPs from opposition parties to agree that "even though we all wish to age happily in our own home, it is not possible for many of us," or that "institutional care is needed when living at home is no longer dignified." Insecurity and reduced functional ability (mental or physical) were often described as factors that would turn the home of an older person into a substandard place to live (see Pulkki et al. 2017). That is, the home was not portrayed as a haven (Mallett 2004).

To sum up, the definition of home was restricted to one's own private and permanent space, while institutional care was referred to as "not being anyone's home" and sheltered housing was "an alternative to one's own home." There was an absence in parliamentary discussions of statements related to meaningful surroundings, emotional ties or other positive attributes of the home, and thus the home could be interpreted as resembling a restricted and objective space rather than an outward-looking place of belonging (Easthope 2004; Ewart \& Luck 2013; Mallett 2004; Oswald \& Wahl 2005). The home as a restricted space is described in more detail in the subthemes discussed below.

Home as a restricted space where older people "manage to live." The home could be depicted as a restricted space where older people "manage to live." This subtheme was constituted from comments where the MPs 
International Journal of Ageing and Later Life

pictured how older people lived, that is, what they did in their homes. Instead of using verbs such as enjoying, living actively and so forth, MPs often used the words "managing," "surviving" and "coping" when referring to living at home. The home was depicted as a space where one survives (or not) by the MPs from both government and opposition parties:

Older people are healthier than before, and they can manage at home longer with home care services. (Gov., 2014)

The home is certainly the best place for all of us, while we can cope there, and if we get help. (Opp., 2014)

Continuing to manage to live at home was mostly enabled by offering services - but rarely, for example, by adjusting the living conditions, which is also considered an essential facilitator for older people to maintain the balance between their experienced and imagined home (Watkins \& Hosier 2005). MPs often presented situations, such as having problems with memory, reduced functional ability and insecurity, where older persons were no longer able to manage to live at home and needed to move somewhere else.

In our previous studies on MPs' talk, we found that MPs portrayed others, especially formal carers, as active agents in older people's lives over the older people themselves. This was also the case when MPs talked about the means by which "we support older people managing to live at home." Older people were not considered active participants in their care, even though caring takes place in older persons' own homes (Pulkki \& Tynkkynen 2015; Pulkki et al. 2017).

Home as a restricted space where older people "are treated." Extracts demonstrating the purpose of the home constituted the second subtheme. In these extracts, the home was viewed as a restricted space where older people "are treated." In contrast to the literature, the home was not, for example, a place for social life (Nicholson et al. 2013; Sixsmith \& Sixsmith 2008) or a place that supported older people's self-image and identity (Haak et al. 2007; Kontos 1998). Even though MPs considered independent living an important facet of late-life, the home was not stated to contribute 
to independence, in spite of numerous studies that have demonstrated this (Haak et al. 2007; Kontos 1998; Sixsmith \& Sixsmith 2008).

This theme stressed the notion of home as a functional space. That is, a space where services such as home care and rehabilitation were offered, not because these were necessary for an older person, but rather because these services would extend the time the older persons lived at home. The care offered in institutions was relocated to the home, as exemplified by the following excerpts where an MP contested the long-term care wards in health centres that were seen as violating older patients' physical functioning:

We need to change our thinking ... towards maintaining the ability to function for a longer period in late life. In order to do this, we need stronger services to be offered at home. (Gov., 2014)

The home was also turned into a care site in the opening speech by the MP from the government who presented how, by defining the home as a "unit for action," the care regulations could be applied also there and not just in institutions:

Unit for action is defined in the Act so that it also includes, for example, home services, meaning that the home is also in this sense a unit for action. (Gov., 2012)

References to the home as a "unit for action" underline the view of the home as a limited physical space for care (see Ewart \& Luck 2013; Mallett 2004).

This theme also included examples where care at home was not seen as the best option. MPs, especially those from the opposition parties, were concerned about the quality of services offered at home. They often suggested that institutional care might be a better option than living at home. Some arguments depicted the home as a site of insufficient care, for example, "institutional care could be a better option than a home where someone just chucks the medicines in from the doorstep (Opp., 2012)".

All in all, rather than acknowledging the subjective purpose of the home, the purpose of the home was determined objectively (Oswald \& Wahl 2005) from the service providers' perspective. 
International Journal of Ageing and Later Life

Home as a restricted space where older people "live without contacts." The third subtheme consisted of clear statements related to older people's lives at home, but this theme also noted what was missing from the discussions. Older people living at home were stripped of any glamour, enjoyment or even a good life. Far from mentioning the positive attributes of life at home, these data extracts often depicted it as tedious and lonely, especially when MPs questioned living at home:

\footnotetext{
...our older people live 22 hours a day alone in their home, and for many, loneliness is one of the biggest problems in life. (Opp., 2014)

It would be the ideal situation for a nurse to be always available at home, but that is not the reality; instead, it is lonesome being at home. (Opp., 2014)
}

Formal carers have free and unfettered admittance to otherwise closed homes. Apart from formal carers, hardly any other connections or contacts with significant others, relatives or friends were mentioned in the MPs' talk about older people's lives at home. The home was not depicted as a place for social contact. Home-dwelling older people had opted out of any social life, even though in practice, they still lived within the community. This kind of home could be interpreted as a limited and narrow space disconnected from the surrounding environment (Ewart \& Luck 2013; Mallett 2004).

If the home is considered to be disconnected, it may also be seen as easily exchangeable for other places and other forms of living. The supposed ease of leaving home and moving to another place was shown in the following extract, where one MP talked about building houses in "normal living areas" in city centres, into which older people could move:

\footnotetext{
...this current situation certainly cannot be the ideal one, that homes' locations are scattered, and it is difficult to get services to them, but hopefully, municipalities can... offer houses for older people within the normal living areas, in order to bring the services there. (Gov., 2014)
}

This argument was presented with no serious thought about the importance of continuity in social contacts or familiar surroundings - things that make a home (Hillcoat-Nallétamby \& Ogg 2014; Mackenzie et al. 2015; Stones \& Gullifer 2016). 


\section{Discussion}

This study aimed to explore how policymakers depicted the home when they were debating living arrangements and care for older people. By this, we aimed to shed light on the grounds of the current policy of ageing in place. In order to achieve these aims, two parliamentary debates regarding the legislative processes surrounding the Act on Supporting the Functional Capacity of the Older Population and on Social and Health Care Services for Older Personse were analysed. The data used here had both advantages and limitations. The parliamentary debates opened a window that allowed an analysis of the policymakers' underlying views of the home while they were forging ageing in place policies. At the same time, the aims and nature of the Act the MPs were debating about shaped the results. For example, the home was mostly depicted from the point of view of an older person who needed services and care (see Pulkki \& Tynkkynen 2015). This may not be problematic, however, as this is the focus group of old-age policy, including ageing in place policy, in general.

In the discussions, the homes of older people were portrayed as restricted spaces where people were mainly managing their lives and in which they received treatment. The concept of home that appeared in these discussions referred mostly to private houses or apartments, and the home was described as a space defined by four walls. At the same time, the importance of surroundings and social relationships were not acknowledged. Besides, the discussions included almost no references to older people's significant others. That is, the home could be depicted as an empty space.

The home appeared to be a confined and withdrawn physical space, as distinguished from an open-ended place that continues into its surroundings (see Easthope 2004; Mallett 2004). Nor was the home portrayed as a haven that offered security, privacy or comfort (see Mallett 2004). Even though the MPs considered the home to be the best place for older people to live, the home was not romanticised. Instead, it was seen as a fairly tedious space with no emotional purpose. There were no suggestions about the personal significance of home for the dwellers. Instead, the home was approached from a practical point of view - as a site for care. Thus, it could be interpreted that the home in these policy discussions was a "cold space" rather than a "warm place" (see Rubinstein \& de Medeiros 2005: 59). 
International Journal of Ageing and Later Life

We can assume that MPs against and for home-centred old-age policy had similar opportunities in stating their cases. However, while MPs mentioned several and different kinds of downsides to the home, they did not specify the positive qualities of the home, even though these are well-known based on the research literature. Downsides were probably discussed more thoroughly to counter the deeply seated view of the home being the best place for older people, which was also often mentioned in discussions. This view could be said to be the cornerstone of home-centred old age and ageing in place policies and is probably so self-evident that it is not even considered needing any complementary explanations. MPs against the strict home-centred policy also had much "evidence" to build on their argument - they used stories and examples from their own real-world experiences, or they referred to news about problems in oldage care at home. It might be more challenging to put it in words as to why the home is the best place, especially if you are not familiar with the research related to it.

According to previous research, for older people themselves, the home is far more than four walls or a limited physical space where one receives care and just gets by. Rather, the home is a part of who older persons are, and living at home is an opportunity to continue a socially and emotionally enriched life in familiar surroundings (Stones \& Gullifer 2016). Unlike the literature, the MPs misrecognised the importance of neighbours and community (Mackenzie et al. 2015; Nicholson et al. 2013), and maintaining familiar surroundings - not just in a particular house (e.g. Hillcoat-Nallétamby \& Ogg 2014) - was downplayed in the discussions. Van Hees et al. (2018) made a similar finding in a study where they examined the meanings that local policymakers, directors and older people's representatives gave to ageing in place.

Older people's loneliness was regularly foregrounded. Thus, MPs shared the concern, also presented in many studies, that loneliness is an evident drawback of living at home (Eloranta et al. 2015; Savikko et al. 2005; Theeke 2009). The MPs recognised the need for alternative places to live when "the time comes" (see Pulkki et al. 2017). This observation is in line with what is known about older adults' preferences regarding living at home. It has been shown that the meaning of home maintains its ability to improve people's quality of life even in times of illness, but it also has its 
limits. Older persons prefer living at home when they anticipate a healthy old age, but when physical or cognitive limitations or death are foreseen, one's private home becomes an undesired place (Fernández-Carro 2016; Gott et al. 2004; Seymour et al. 2007).

Alternative dwelling places for older people were offered in these debates (Pulkki et al. 2017), but these choices were no longer considered to be homes in the most profound sense. Institutions were said to be nonhomes, and service houses were described as being less of a home than one's "permanent" or "current" home. It was not considered that older people might carry the home with them (Ewart \& Luck 2013; Vilkko 2000), nor that a new living place can be "home enough" (Vilkko 2000). From the perspective of home-centred policy, it becomes increasingly important to understand that while living at home may be desirable, it is also possible to help people feel at home, even if they have had to move on in old age. Older people may "age out" of one place, but not out of the home.

According to our analysis, policymakers appeared to misrecognise the continuity, meaningfulness and supportive nature of staying at home when they were forging home-centred old-age policies. From a policy perspective, this misrecognition may be problematic. A restricted and onesided view of the home may impede the formulation and implementation of policies as it narrows down the possible solutions for living arrangements. When formulating home-centred old-age policies, it is essential to understand that the home has physical, social, cultural and symbolic dimensions, and that it is a fluctuating venue by nature (see Easthope 2004; Moore 2000).

\section{Declaration of Conflicts}

The authors declare no conflict of interest.

\section{Acknowledgement}

This study was carried out as part of the Social Inequalities in Ageing (SIA) project, funded by NordForsk, project no. 74637. The study is conducted partially in a research environment provided by the Centre of 
International Journal of Ageing and Later Life

Excellence in Research on Ageing and Care (CoE AgeCare) and Gerontology Research Center (GEREC).

\section{Corresponding Author}

Jutta Pulkki, Faculty of Social Sciences, Tampere University; Health Sciences \& CoE AgeCare \& GEREC, FI-33014 Tampereen Yliopisto, Tampere, Finland. Email: jutta.pulkki@tuni.fi

\section{References}

Batljan, I. \& Lagergren, M. (2005). Future demand for formal long-term care in Sweden. European Journal of Ageing 2(3): 216-224.

Borglin, G., Edberg, A.-K. \& Hallberg, I. (2005). The experience of quality of life among old people. Journal of Ageing Studies 19(2): 201-220.

Braun, V. \& Clarke, V. (2006). Using thematic analysis in psychology. Qualitative Research in Psychology 3(2): 77-101.

Chapman, T. \& Hockey, J. (eds.) (1999). Ideal Homes? Social Change and Domestic Life. London: Routledge.

Easthope, H. (2004). A place called home. Housing, Theory and Society 21(3): $128-138$.

Eloranta, S., Arve, S., Isoaho, H., Lehtonen, A. \& Viitanen, M. (2015). Loneliness of older people aged 70: A comparison of two Finnish cohorts born 20 years apart. Archives of Gerontology and Geriatrics 61(2): 254-260.

Ewart, I. \& Luck, R. (2013). Living from home. Home Cultures 10(1): 25-42.

Fernández-Carro, C. (2016). Ageing at home, co-residence or institutionalisation? Preferred care and residential arrangements of older adults in Spain. Ageing and Society 36(3): 586-612.

Finlex. (2012). Act on Supporting the Functional Capacity of the Older Population and on Social and Health Care Services for Older Persons. Unofficial translation. Available on https://www.finlex.fi/fi/laki/ kaannokset/2012/en20120980_20120980.pdf (Accessed: December 25, 2020)

Genet, N., Boerma, W., Kringos, D., Bouman, A., Francke, A. L., Fagerström, C., Melchiorre, M. G., Greco, C. \& Devillé, W. (2011). Home care in Europe: A systematic literature review. BMC Health Services Research 11: 207. 
Gillsjö, C., Schwartz-Barcott, D. \& von Post, I. (2011). Home: The place the older adult cannot imagine living without. BMC Geriatrics 11: 10.

Gomes, B., Calanzani, N., Gysels, M., Hall, S. \& Higginson, I. J. (2013). Heterogeneity and changes in preferences for dying at home: A systematic review. BMC Palliative Care 12: 7.

Gott, M., Seymour, J., Bellamy, G., Clark, D. \& Ahmedzai, S. (2004). Older people's views about home as a place of care at the end of life. Palliative Care 18(5): 460-467.

Haak, M., Fänge, A., Iwarsson, S. \& Ivanoff, S. D. (2007). Home as a signification of independence and autonomy: Experiences among very old Swedish people. Scandinavian Journal of Occupational Therapy 14(1): 16-24.

Van Hees, S., Horstman, K., Jansen, M. \& Ruwaard, D. (2018). Meanings of "lifecycle robust neighbourhoods": Constructing versus attaching to places. Ageing and Society 38(6): 1148-1173.

Hillcoat-Nallétamby, S. \& Ogg, J. (2014). Moving beyond "ageing in place": Older people's dislikes about their home and neighbourhood environments as a motive for wishing to move. Ageing and Society 34(10): 1771-1796.

Johansson, E. (2010). The long-term care system for the elderly in Finland. ENEPRI Research Report 76. Available on https://www.ceps.eu/ ceps-publications/long-term-care-system-elderly-finland (Accessed: December 16, 2019)

Jolanki, O. \& Kröger, T. (2015). Onko vanhalla vara valita? Vanhojen ihmisten uudet asumisvaihtoehdot [Does older person has a change to choose? New living opportunities for older people]. In J. Häkli, R. Vilkko \& L. Vähäkylä (eds.), Kaikki kotona? Asumisen uudet tuulet [All home? The new winds of living arrangements] (pp. 82-92). Helsinki: Gaudeamus.

Kaskiharju, E. (2010) Koteja ja kodinomaisuutta: Tutkimus vanhenemisen paikoista valtiopäiväpuheissa 1950-2005 [Homes and Homelikeness. A Study on Places for Ageing in Parliamentary Speeches from 1950 to 2005]. Jyväskylä: Jyväskylä University Printing House.

Keskimäki, I., Tynkkynen, L-K., Reissel, E., Koivusalo, M., Syrjä, V., Vuorenkoski, L., Rechel, B. \& Karanikolos, M. (2019). Finland: Health System Review. Health Systems in Transition. European Observatory on 
International Journal of Ageing and Later Life

Health Systems and Policies. Available on https://apps.who.int/iris/ bitstream/handle/10665/327538/18176127-eng.pdf?sequence=1\&isAllowed=y (Accessed: December 16, 2019)

Kokko, S. \& Valtonen, H. (2008). Kunnat ja vanhuspalveluiden pitkäaikaishoidon rakennemuutokset [Local authorities and structural changes in long-term care services for the elderly]. Yhteiskuntapolitiikka 73(1): 12-23.

Kontos, P. (1998). Resisting institutionalization: Constructing old age and negotiating home. Journal of Aging Studies 12(2): 167-184.

Mackenzie, L., Curryer, C. \& Byles, J. (2015). Narratives of home and place: Findings from the Housing and Independent Living Study. Ageing and Society 35(8): 1684-1712.

Mallett, S. (2004). Understanding home: A critical review of the literature. Sociological Review 52(1): 62-89.

Means, R. (2007). Safe as houses? Ageing in place and vulnerable older people in the UK. Social Policy and Administration 41(1): 65-85.

Ministry of Social Affairs and Health. (2001). Ikäihmisten hoitoa ja palveluja koskeva laatusuositus [Quality Recommendation on Care and Services for the Elderly]. Sosiaali- ja terveysministeriön oppaita 2001:4. Available on http:/ / urn.fi/URN:NBN:fi-fe201309236165 (Accessed: December 16, 2019)

Ministry of Social Affairs and Health. (2008). Ikäihmisten palvelujen laatusuositus [Quality Recommendation for Elderly Services]. Sosiaali- ja terveysministeriön julkaisuja 2008:3. Available on http://urn.fi/ URN:NBN:fi-fe201504225987 (Accessed: December 16, 2019)

Moore, J. (2000). Placing home in context. Journal of Environmental Psychology 20: 207-217.

Mortenson, W., Sixsmith, A. \& Beringer, R. (2016). No place like home? Surveillance and what home means in old age. Canadian Journal on Aging 35(1): 103-114.

Nicholson, C., Meyer, J., Flatley, M. \& Holman, C. (2013) The experience of living at home with frailty in old age: A psychosocial qualitative study. International Journal of Nursing Studies 50(9): 1172-1179.

Official statistics of Finland. (2018). Sosiaali- ja terveysalan tilastollinen vuosikirja 2018 [Statistical yearbook on social welfare and health care 2018]. Helsinki: PunaMusta Oy. 
Oswald, F. \& Wahl, H.-W. (2005). Dimensions of the meaning of home in later life. In G. Rowles \& H. Chaudhury (eds.), Home and Identity in Late Life: International Perspectives (pp. 21-45). New York: Springer

Pirhonen, J., Ojala, H., Lumme-Sandt, K. \& Pietilä, I. (2015). “Old, but not that old": Finnish community dwelling people aged 90+ negotiating their autonomy. Ageing and Society 36(8): 1625-1644.

Pirhonen, J. \& Pulkki, J. (2016). Sosiaali- ja terveydenhuollon perusarvojen jäljillä: Avuntarpeen ja riippuvuuden tunnustaminen vanhuspalveluissa [Tracking the basic values in social and health care services - recognizing the need for help and dependence in elderly care]. Janus 24(3): 251-264.

Pulkki, J. \& Tynkkynen, L-K. (2015). "All elderly people have important service needs": A study of discourses on older people in parliamentary discussions in Finland. Ageing and Society 36(1): 64-78.

Pulkki, J., Tynkkynen, L-K. \& Jolanki, O. (2017). Aktivoivat, muuttuvat ja sopimattomat vanhe-nemisen paikat. Analyysi vanhuspalvelulain lähetekeskustelusta [Places of ageing in parliamentary debates in Finland]. Yhteiskuntapolitiikka 82(1): 45-54.

Rowles, G. \& Chaudhury, H. (eds.) (2005). Home and Identity in Late Life: International Perspectives. New York: Springer.

Rubinstein, R. \& de Medeiros, K. (2005). Home, self, and identity. In G. Rowles \& H. Chaudhury (eds.), Home and Identity in Late Life: International Perspectives (pp. 47-62). New York: Springer.

Savikko, N., Routasalo, P., Tilvis, R., Strandberg, T. E. \& Pitkälä, K. H. (2005). Predictors and subjective causes of loneliness in an aged population. Archives of Gerontology and Geriatrics 41(3): 223-233.

Seymour, J., Payne, S., Chapman, A. \& Holloway, M. (2007). Hospice or home? Expectations of end-of-life care among white and Chinese older people in the UK. Sociology of Health and Illness 29(6): 872-890.

Sixsmith, A. \& Sixsmith, J. (2008). Ageing in place in the United Kingdom. Ageing International 32(3): 219-235.

Starke, P. (2006). The politics of welfare state retrenchment: A literature review. Social Policy and Administration 40(1): 104-120.

Statfin. (2016). Statistics Finland PX-web Database. Available on http://tilastokeskus.fi/tup/tilastotietokannat/index.html. (Accessed: December 14, 2016) 
International Journal of Ageing and Later Life

Stones, D. \& Gullifer, J. (2016). “At home it's just so much easier to be yourself": Older adults' perceptions of ageing in place. Ageing and Society 36(3): 449-481.

Tarricone, R. \& Tsouros, A. (eds.) (2008). Home Care in Europe. Copenhagen: World Health Organization.

Theeke, L. (2009). Predictors of loneliness in U.S. adults over age sixty-five. Archives of Psychiatric Nursing 23(5): 387-396.

Vilkko, A. (2000). Riittävästi koti [Home enough]. Janus 8(3): 213-230.

Watkins, J. \& Hosier, A. (2005). Conceptualizing home and homelessness: A life course perspective. In G. Rowles \& H. Chaudhury (eds.), Home and Identity in Late Life: International Perspectives (pp. 197-216). New York: Springer.

Wiles, J., Leignig, A., Guberman, N., Reeve, J. \& Allen, R. E. (2012). The meaning of "aging in place" to older people. Gerontologist 52(3): 357-366. 